\title{
Inheritance of resistance to downy mildew (Pseudoperonospora cubensis) in muskmelon (Cucumis melo). II. Generation means analysis of 5 genitors
}

\author{
C Épinat ${ }^{1 *}$, M Pitrat $^{2}$ \\ 1 INRA-CNRS-UPS, Station de Génétique Végétale, Ferme du Moulon, F91190 Gif-sur-Yvette; \\ 2 INRA, Station d'Amélioration des Plantes Maraíchères, BP 94, F84143 Montfavet, France
}

(Received 27 August 1993; accepted 12 April 1994)

\begin{abstract}
Summary - The contribution of the generation means analysis described by Mather and Jinks to the genetic analysis of resistance to downy mildew caused by Pseudoperonospora cubensis in muskmelon (Cucumis melo $\mathrm{L}$ ) was examined. Five melon cultivars with high to moderate levels of resistance to $P$ cubensis were crossed with 3 susceptible cultivars to develop $F_{1}, F_{2}$ and back-cross generations. Weighted least-square regression analysis indicated that the majority of the variation could be explained by additive effects (84-99\%); epistasis effects are the second-most important effects (explaining at most $8 \%$ ). Dominance ratio, heritability and number of effective factors could be estimated in the crosses that did not exhibit epistasis. All these genetic parameters showed an important variation among the 15 crosses studied. Analysis of the results led to the proposal of a breeding strategy for the resistance character.
\end{abstract}

\section{Cucumis melo / metrical analysis / inheritance / Pseudoperonospora cubensis / resistance}

Résumé - Hérédité de la résistance au mildiou (Pseudoperonospora cubensis) chez le melon (Cucumis melo). II. Analyse métrique de 5 géniteurs. L'apport de l'analyse métrique (Mather et Jinks, 1971) dans l'étude de la génétique de la résistance du melon (Cucumis melo) au mildiou (Pseudoperonospora cubensis) est évalué. Cinq cultivars de melon, avec des niveaux de résistance modéré à élevé, ont été croisés à 3 variétés sensibles : les générations F1, F2 et les back-cross par les 2 parents ont été obtenues. La régression pondérée des moyennes des différentes générations sur un modèle génétique théorique indique que la majorité de la variation est expliquée par les effets additifs (81-99\%). Les effets d'épistasie sont la deuxième plus importante cause de variation (expliquant au maximum $8 \%$ du total). Les ratios de dominance, les héritabilités et le nombre de facteurs effectifs ont pu être estimés dans les croisements ne montrant pas d'effets épistatiques. Tous ces paramètres génétiques sont très variables entre les 15 croisements étudiés. L'analyse des résultats conduit à l'élaboration d'une stratégie de sélection pour le caractère de résistance considéré.

Cucumis melo / analyse métrique / hérédité / Pseudoperonospora cubensis / résistance

\section{INTRODUCTION}

Downy mildew caused by Pseudoperonospora cubensis (Berk and Curt) Rost is an important disease on cucurbits in humid areas of production throughout the world (Cohen, 1981). This disease appeared in France on melon cultures in
1984 and has since been commonly found in the main French production areas. In 1992, downy mildew was the most devastating pathogen on melon cultures. Chemical control of the disease is mainly protective, and so the development of commercially acceptable resistant cultivars is urgent.

\footnotetext{
* Correspondence and reprints
} 
The inheritance of resistance of several cultivars has been recently investigated. Three plant introductions, 'MR-1', 'PI 124111F' and 'PI 124112', were extensively studied (Cohen et al, 1985; Thomas et al, 1988; Kenigsbuch and Cohen, 1989, 1992). 'MR-1' and 'PI 124111F' are inbred lines derived from ' $\mathrm{PI}$ 124111' population in the USA (Thomas and coworkers) and Israel (Cohen and coworkers) respectively. Cohen et al, Kenigsbuch, Cohen and Thomas all reported that 2 incompletely dominant genes (Pc-1 and Pc-2) confer resistance in ' $P$ I 124111F' and 'MR-1'. Kenigsbuch and Cohen (1992) reported 2 partially dominant genes conferring resistance in ' $\mathrm{PI}$ 124112 ', one of which would be common with 'MR-1' (the other was symbolized Pc-4). Because all these authors ordered individuals into 2 or 3 classes (resistant; intermediate; susceptible), they found monogenic or digenic controls. Moreover only one susceptible control was used in these studies. The originality of the present work is to consider 5 resistant or at least partially resistant melon introductions in crosses with 3 susceptible cultivars and to assess resistance in a quantitative way.

The back-cross technique is widely used to improve resistance in melon. This requires the knowledge of genetic parameters relative of a single genitor. Through analysis of the segregating generations issued from each 'resistant $x$ susceptible' $F_{1}$ cross, we will: i) determine the type of gene action controlling resistance; ii) estimate components of the genetic variation; iii) provide heritability estimates; and iv) estimate the minimum number of effective factors segregating in each 'resistant $x$ susceptible' cross.

\section{MATERIALS AND METHODS}

\section{Crosses}

Five plant introductions with a high or partial level of resistance were studied. Four cultivars were from India: 'MR-1' (higher level of resistance: infected leaves showed no sporulation but pin-prick brown lesions); 'PI 124112' (small brown lesions and traces of sporulation on infected leaves); 'PI 164323' (small necrotic lesions with light sporulation); and 'PI 414723' (medium-sized brown lesions with light sporulation). 'Edisto 47 ' is an American variety derived from ' $\mathrm{Pl}$ 124112' (medium-sized brown lesions with moderate sporulation); 'Védrantais' and 'Charentais T' are 2 susceptible lines in the Charentais type commonly cultivated in France (with 'Védrantais' slightly more susceptible than 'Charentais T'); and 'Ouzbèque' is a highly susceptible line from Uzbekistan.
The $F_{1}, F_{2}$ and backcross generations ( $B C 1=F_{1} x$ susceptible parent and $B C 2=F_{1} \times$ resistant parent) from the crosses between each resistant line and the susceptible varieties 'Védrantais', 'Charentais T' and 'Ouzbèque' were obtained. Two hundred plants of the $F_{2}$ progeny, 100 plants of each backcross and 30 plants of parental and $F_{1}$ generations were tested with $P$ cubensis in 2 replications (each containing $100 F_{2}$, $50 \mathrm{BC}$ and 15 parents and $F_{1}$ ).

\section{Isolates and conservation technique}

An isolate of pathotype 3 was used (Epinat, 1992). The technique of conservation was the same as described by Épinat and Pitrat (1994).

\section{Plant culture, inoculation procedure and disease rating}

The leaf-disk test described by Blancard et al (1989) was applied to all plants at the 2-3 leaf stage. The inoculation procedure and the disease rating have been previously described (Épinat and Pitrat, 1994).

\section{Data analysis}

Generation means analysis was performed for each 'resistant $x$ susceptible' cross according to the general model of Mather and Jinks (1971):

$$
Y=m+\alpha[d]+\beta[h]+\alpha^{2}[i]+2 \alpha \beta[j]+\beta^{2}[l]
$$

where $m=$ grand mean, $[d]=$ homozygous and $[h]=$ heterozygous effects, $[i]=$ homozygous $\mathrm{x}$ homozygous, $[j]=$ homozygous $x$ heterozygous and $[/]=$ heterozygous $x$ heterozygous epistatic effects. $\alpha$ and $\beta$ are coefficients depending on generations as shown in the following matrix:

$\left|\begin{array}{l}\overline{\mathrm{P} 1} \\ \overline{\mathrm{P} 2} \\ \overline{\mathrm{F} 1} \\ \overline{\mathrm{F} 2} \\ \overline{\mathrm{BC} 1}\end{array}\right|=\left|\begin{array}{cccccc}1 & 1 & 0 & 1 & 0 & 0 \\ 1 & -1 & 0 & 1 & 0 & 0 \\ 1 & 0 & 1 & 0 & 0 & 1 \\ 1 & 0 & 1 / 2 & 0 & 0 & 1 / 4 \\ 1 & 1 / 2 & 1 / 2 & 1 / 4 & 1 / 4 & 1 / 4 \\ 1 & -1 / 2 & 1 / 2 & 1 / 4 & -1 / 4 & 1 / 4\end{array}\right|\left|\begin{array}{l}{[m]} \\ {[d]} \\ {[h]} \\ {[j]} \\ {[j]} \\ {[l]}\end{array}\right|[2]$

Since variances within each generation were not equal, the analysis had to be done on weighted means. The weight commonly used (Mather and Jinks, 1971) was the inverse of the variance of the mean of each particular generation. This analysis used the multiple and stepwise regression technique and chose the model that best fitted the data. The goodness of fit of the model was checked by a weighted $\chi^{2}$ (Cavalti, 1952). The weighted least-squares regression technique allowed the estimation of the significant genetic $([d],[h],[i],[j],[l])$ and environmental $([e])$ parameters 
of the model. The environmental effect was estimated with the 2 replications of the test. When it was non-significant, the analysis was performed on generation means pooled over the 2 environments. Student tests of significance for the genetic parameters were provided by the regression technique (least-squares estimate / standard deviation).

Variance components, $E, D$ and $H$ representing the environmental, additive and dominance genetic variances, respectively, were estimated as follows:

$$
\begin{aligned}
& E=1 / 4 V_{P 1}+1 / 4 V_{P 2}+1 / 2 V_{F 1} \\
& D=4 V_{F 2}-2\left(V_{B C 1}+V_{B C 2}\right) \\
& H=4\left(V_{B C 1}+V_{B C 2}-V_{F 2}-E\right)
\end{aligned}
$$

where $V_{P 1}, V_{P 2}, V_{F 1}, V_{F 2}, V_{B C 1}$ and $V_{B C 2}$ are the variances of parental, $F_{1}, F_{2}$ and back-crosses generations. Approximate variations of these variances were estimated according to the method of Scheffé (1959).

Broad-sense ( $s /=$ sensu lato) and narrow sense (ss = sensu stricto) heritability were estimated at the $\mathrm{F}_{2}$ generation level by the following formulae (Warner, 1952):

$$
\begin{aligned}
& h_{s l}^{2}=\frac{1 / 2 D+1 / 4 H}{1 / 2 D+1 / 4 H+E} \\
& h_{s s}^{2}=\frac{1 / 2 D}{1 / 2 D+1 / 4 H+E}
\end{aligned}
$$

The standard error of $h_{s s}^{2}$ was calculated according to Ketata et al (1976):

$\sigma_{h_{s S} 2}=\sqrt{2} \frac{\sqrt{\frac{\left(V_{B C 1}+V_{B C 2}\right)^{2}}{d f_{F 2}}+\frac{V_{B C 1}^{2}}{d f_{B C 1}}+\frac{V_{B C 2}^{2}}{d f_{B C 2}}}}{V_{F 2}}$ [8]

where $d f_{F 2}, d f_{B C 1}$ and $d f_{B C 2}$ are the degrees of freedom of the $F_{2}, \mathrm{BC} 1$ and $\mathrm{BC} 2$ generations, respectively.

The number of effective factors segregating in the different crosses was estimated by 4 methods. These methods were based on various combinations of the observed parental, $F_{1}, F_{2}$ and back-cross variances:

$$
n_{1}=\frac{[d]^{2}}{D}
$$

where $[d]$ was the additive effect estimate (Mather and Jinks, 1971);

$$
n_{2}=\frac{(\overline{P 1}-\overline{P 2})^{2}}{8\left(V_{F 2}-E\right)}
$$

where $(\overline{P 1}-\overline{P 2})$ was the difference between observed parental means (Wright, 1968);

$$
n_{3}=n_{2} \times\left[1.5-2 h^{\prime}\left(1-h^{\prime}\right)\right]
$$

where $h^{\prime}$ was the dominance ratio $=[h] /[d]$ (Wright, 1968);

$$
n_{4}=\frac{(\overline{P 1}-\overline{P 2})^{2}}{8\left[2 V_{F 2}-\left(V_{B C r}+V_{B C S}\right)\right]}
$$

from Wright, 1968.

\section{RESULTS}

The $F_{2}$ and back-cross populations did not segregate into distinct categories, indicating that the inheritance of disease reaction to $P$ cubensis was actually a quantitative trait. A perfect fit estimation of the genetic parameters (Mather and Jinks, 1971) was done through generation means analysis for the 15 'resistant $x$ susceptible' crosses (table I). Weighted least-squares regression analysis indicated that only a few parameters among the 7 parameters introduced a priori in the model $(m,[d],[h],[i],[j],[/]$ and $[e])$ were significant. Least-squares estimates of the significant genetic parameters, together with their deviation are presented in table I. All models included the [d] parameter and the corresponding coefficient of determination indicated that at least $84 \%$ of total variation among generations was due to these additive effects. Dominance effects $([h])$ were significant in 3 crosses, all including 'MR-1' or 'PI 124112'. These effects had a low impact on total variation as the greatest coefficient of determination assigned to [h] did not exceed $3 \%$. Epistatic effects significantly appeared in 3 crosses involving varieties 'MR-1', 'PI 124112' and 'Edisto 47 ' and explained at most $8 \%$ of total variation (cross 'MR-1 $x$ Charentais T'). In the other 2 cases these effects contributed about $3 \%$ of total variation. Thus, non-additivity (dominance and epistasis) explained a small part of the genetic variation compared with additive effects. The environmental effect corresponding to the 2 repetitions of a test ([e]) was significant in 3 crosses but the proportion of total variance explained did not exceed $3 \%$. The values of weighted $\chi^{2}$ in all cases indicated a good fit to the data $\left(P\left(\chi^{2}>\chi_{0}^{2}\right)\right.$ $\geq 0.64$ ) (table l).

Variance component analysis provided the estimates of components of genetic variation, dominance ratio and heritabilities (table II). Environmental variation was, in all cases, lower than genetic variance but could not be neglected. The additive component of genetic variation was 
Table I. Generation means analysis of crosses (resistant $x$ susceptible). Significant genetic parameters and their standard deviations are computed. The corresponding determination coefficient $\left(R^{2}\right)$ are indicated. Joint scaling test $\left(\chi^{2}\right)$ determine the suitability of the genetic model according to Mather and Jinks (1971).

Parameters * $\quad x$ Charentais $T$

Mean $\pm \sigma \quad P\left(T>T_{0}\right) \quad R^{2}$

$\frac{x \text { Védrantais }}{\text { Mean } \pm \sigma \quad P\left(T>T_{0}\right) \quad \mathrm{R}^{2}}$

$\frac{x \text { Ouzbèque }}{\text { Mean } \pm \sigma \quad \mathrm{P}\left(\mathrm{T}>\mathrm{T}_{0}\right) \quad \mathrm{R}^{2}}$

MR-1

$\begin{array}{lccc}m & 1.94 \pm 0.06 & 0.001 & - \\ {[d]} & 2.71 \pm 0.04 & 0.0002 & 0.92 \\ {[h]} & - & - & \\ {[i]} & 0.87 \pm 0.07 & 0.007 & 0.07 \\ {[j]} & 1.92 \pm 0.24 & 0.015 & 0.01 \\ {[l]} & - & - & - \\ {[e]} & - & - & -\end{array}$

$\begin{array}{ll}\chi^{2}(d f) & 0.17 \\ P\left(\chi^{2}>\chi_{0}^{2}\right) & 0.99\end{array}$

PI 124112

$\begin{array}{rcc}3.48 \pm 0.07 & 0.0001 & - \\ 3.34 \pm 0.07 & 0.0001 & 0.97 \\ -2.16 \pm 0.26 & 0.0004 & 0.03 \\ - & - & - \\ - & - & - \\ - & - & - \\ - & - & -\end{array}$

0.27 0.96

(3)

$\begin{array}{ccc}4.13 \pm 0.01 & 0.0001 & - \\ 3.63 \pm 0.01 & 0.0001 & 0.97 \\ 0.28 \pm 0.01 & 0.007 & 0.0001 \\ - & - & - \\ -0.68 \pm 0.01 & 0.003 & 0.0006 \\ 1.91 \pm 0.01 & 0.001 & 0.023\end{array}$

0.00

0.99

(1)

0.96

$\begin{array}{rcc}3.94 \pm 0.06 & 0.0001 & - \\ 3.77 \pm 0.06 & 0.0001 & 0.98 \\ -1.68 \pm 0.21 & 0.007 & 0.01 \\ - & - & - \\ - & - & - \\ - & - & - \\ -0.10 \pm 0.04 & 0,044 & 0.001\end{array}$

0.66

0.99
(8)
0.63

$\begin{array}{ccc}4.15 \pm 0.13 & 0.0001 & - \\ 3.92 \pm 0.14 & 0.0001 & 0.99 \\ - & - & - \\ - & - & - \\ - & - & - \\ - & - & - \\ - & - & -\end{array}$

(4)

PI 164323

\begin{tabular}{|c|c|c|}
\hline$m$ & \multicolumn{2}{|c|}{$3.37 \pm 0.24$} \\
\hline [d] & & \\
\hline [h] & & \\
\hline [i] & & \\
\hline [i] & & \\
\hline$[/]$ & & \\
\hline [e] & & \\
\hline$\chi^{2}$ & & 1.01 \\
\hline$P(\chi$ & & 0.91 \\
\hline
\end{tabular}

$\begin{aligned} 3.51 & \pm 0.08 \\ 3.02 & \pm 0.11 \\ - & \\ - & \\ - & \\ - & \\ - & \\ & \\ & 0.12 \\ & 0.99\end{aligned}$

$\begin{array}{cc}0.001 & - \\ 0.001 & 0.99 \\ - & - \\ - & - \\ - & - \\ - & - \\ - & -\end{array}$

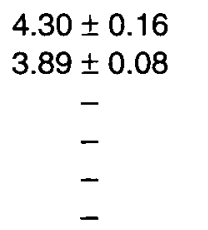

0.0001 $0.0001 \quad 0.99$

$0.25 \pm 0.07$

(4)

0.99

(9)

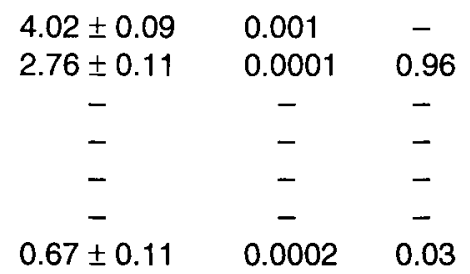

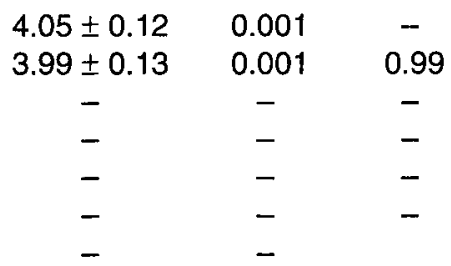

0.42

0.98
(4)

$\chi^{2}(d f)$
$P\left(\chi^{2}>\chi_{0}^{2}\right)$

1.89

(9) 


\begin{tabular}{|c|c|c|c|c|c|c|c|c|c|}
\hline \multirow[t]{2}{*}{ Parameters } & \multicolumn{3}{|c|}{$x$ Charentais $T$} & \multicolumn{3}{|c|}{ x Védrantais } & \multicolumn{3}{|c|}{ x Ouzbèque } \\
\hline & Mean $\pm \sigma$ & $P\left(T>T_{0}\right)$ & $\mathrm{R}^{2}$ & Mean $\pm \sigma$ & $P\left(T>T_{0}\right)$ & $\mathrm{R}^{2}$ & Mean $\pm \sigma$ & $P\left(T>T_{0}\right)$ & $\mathrm{R}^{2}$ \\
\hline \multicolumn{10}{|l|}{ Edisto 47} \\
\hline$m$ & $1.79 \pm 0.08$ & 0.001 & - & $4.37 \pm 0.28$ & 0.001 & - & $5.46 \pm 0.21$ & 0.0001 & - \\
\hline$[d]$ & $1.21 \pm 0.04$ & 0.001 & 0.97 & $1.70 \pm 0.38$ & 0.011 & 0.84 & $2.61 \pm 0.26$ & 0.0001 & 0.96 \\
\hline$[h]$ & - & & - & - & - & - & - & - & - \\
\hline$[i]$ & $-0.54 \pm 0.09$ & 0.01 & 0.03 & - & - & - & - & - & - \\
\hline$[j]$ & - & & - & - & - & - & - & - & - \\
\hline$[/]$ & - & & - & - & - & - & - & - & - \\
\hline$[e]$ & - & & - & - & - & - & - & - & - \\
\hline$\chi^{2}(d f)$ & 0.13 & (3) & & 0. & 8 & & & 0.84 & (4) \\
\hline$P\left(\chi^{2}>\chi\right.$ & 0.99 & & & 0. & & & & 0.93 & \\
\hline
\end{tabular}

${ }^{*} m=$ Midparent point, $[d]=$ homozygous effects, $[h]=$ dominance effects, $[i]=$ homozygous $x$ homozygous epistasis, $[j]=$ homozygous $\mathrm{x}$ heterozygous epistasis, $[/]=$ heterozygous $\mathrm{x}$ heterozygous epistasis and $[e]=$ environmental effect.

estimated to be significantly positive in all 15 crosses as opposed to the dominant component, which appeared significantly positive in only 6 crosses and could not be considered as significantly different from zero in 3 cases (because of negative estimates). For these 3 crosses, estimations of dominance ratio and sensu lato heritability were impossible. When the dominance ratio was equal to 1 (or was between 1 and 1.25 because of sampling error) and no epistasis was detected, we could assume that dominance was complete. This is the case with 5 crosses: 'MR-1 $x$ Védrantais', 'PI $164323 \times$ Charentais T', 'PI $164323 \times$ Ouzbèque', 'PI 414723 x Védrantais' and 'Edisto $47 \times$ Védrantais'. When significant epistatic effects were observed, components of genetic variation ( $D$ and $H$ ) were biased and consequently dominance ratio or heritability estimations were invalidated (cases of 'MR-1 $x$ Charentais T', 'PI $124112 \times$ Védrantais' and 'Edisto $47 \times$ Charentais T'). No evidence of partial dominance $(\sqrt{H / D}<1)$ was found. Broad sense heritability, when estimated, was moderate to high $(0.46-0.73)$. Narrow sense heritability presented a larger range of variation, from nonsignificance (in 2 crosses: ' $P$ I $164323 x$ Charentais $T$ ' and 'Edisto $47 \times$ Védrantais' showing no epistatic effects) to 0.94 . The largest values were obtained when dominance variance was not significant and appeared more frequently with 'Charentais T' and 'Ouzbeque'.

The estimates of minimum number of effective factors controlling $P$ cubensis resistance in all 'resistant $\mathrm{x}$ susceptible' crosses are presented in table III. On the whole, a good homogeneity was observed between the 4 estimates. The effective number of factors of a single genitor varied according to the susceptible parent involved in the cross and we could not infer a general rule governing these variations: eg crosses involving 'Ouzbèque' could either show lower (case of 'MR-1', 'PI 124112') or higher ('PI 164323' or 'Edisto 47') numbers of factors than crosses involving 'Védrantais' or 'Charentais T'. 'PI 164323' showed the largest variation observed among crosses with the susceptible cultivars because of the estimation of numerous factors in its cross with 'Ouzbèque'. In this particular case, a bias may exist due to the significant environmental effect previously detected and so the results should be confirmed with another resistance test (table I).

\section{DISCUSSION AND CONCLUSIONS}

The development of a leaf-disk test (Blancard et al, 1989) allowed us to evaluate resistance on a continuous scale (our score is representative of percentage of leaf surface covered with sporulation). Consequently, the resistance character could be treated as a quantitative character and classical quantitative genetic analysis was justified.

The generation means analysis suggested that additive gene effects played a major role in the determination of genetic variation. This was 
Table II. Components of genetic variation computed for the 15 (resistant $\mathrm{x}$ susceptible) crosses.

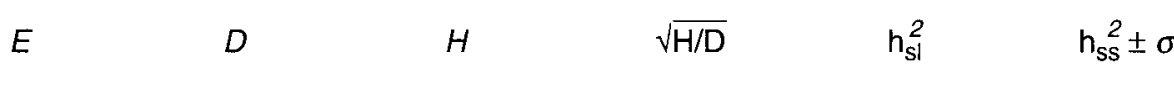

MR-1

$\begin{array}{lllllll}\text { x Charentais T } & 0.40 & 1.48 & -0.09^{\text {ns }} & - & - & 0.65^{\star \star} \\ & 0.14 & 0.32 & 0.46 & & & 0.19 \\ \text { x Védrantais } & 0.68 & 2.06 & 2.72^{\star *} & 1,15 & 0,72 & 0.43^{*} \\ & 0.28 & 0.84 & 1.11 & & & 0.25 \\ \text { x Ouzbèque } & 0.92 & 5.86 & -1.11^{\text {ns }} & - & - & 0.76^{\star *} \\ & 0.34 & 0.97 & & & & 0.18\end{array}$

Pl 124112

$\begin{array}{lllllll}\text { x Charentais T } & 0.69 & 1.65 & 0.96^{\text {ns }} & - & - & 0.54^{\star *} \\ & 0.24 & 0.52 & 0.70 & & & 0.22 \\ \text { x Védrantais } & 0.98 & 3.33 & 3.88^{\star *} & 1.08 & 0.73 & 0.46^{*} \\ & 0.35 & 1.12 & 1.45 & & & 0.23 \\ \text { x Ouzbèque } & 0.54 & 4.70 & 0.74^{\text {ns }} & - & - & 0.81^{* *} \\ & 0.20 & 0.82 & 1.01 & & & 0.17\end{array}$

PI 164323

$\begin{array}{llll}\text { x Charentais T } & 1.25 & 2.52 & 3.98^{\star *} \\ & 0.44 & 1.09 & 1.45 \\ \text { x Védrantais } & 0.49 & 4.83 & 1.45^{\text {ns }} \\ & 0.17 & 0.89 & 1.09 \\ \text { x Ouzbèque } & 0.98 & 0.94 & 1.48^{\star *} \\ & 0.42 & 0.39 & 0.52\end{array}$

1.26

0.64

$0.36^{\text {ns }}$

0.23

$.45^{\mathrm{ns}}$

$0.83^{\star \star}$

$1.48^{* \star}$

0.18

0.42

0.52

1.25

$0.26^{* *}$

0.06

PI 414723

\begin{tabular}{|c|}
\hline$x$ Charentais $T$ \\
\hline$x$ Védrantais \\
\hline x Ouzbèque \\
\hline
\end{tabular}

0.68

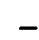

$0.88^{*}$

1.24

$2,58^{* *}$

2.50

1.07

1.01

0.32

0,84

0.82

$-3.05^{\mathrm{ns}}$

$0.46^{*}$

8.30

1.30

0.22

$0.80^{\text {** }}$

$0.31 \quad 1.30$

.

0.15

Edisto 47

\begin{tabular}{lllllll} 
x Charentais T & 0.14 & 4.55 & $-1.92^{\mathrm{ns}}$ & - & - & $0.94^{*}$ \\
& 0,05 & 0.36 & & & & 0.46 \\
x Védrantais & 1.37 & 2.79 & $4.11^{\star \star}$ & 1.21 & 0.64 & $0.37^{\mathrm{ns}}$ \\
& 0.44 & 1.19 & 1.58 & & & 0.23 \\
\multirow{3}{*}{ x Ouzbèque } & 1.02 & 6.15 & $-3.94^{\mathrm{ns}}$ & - & - & $0.75^{\star \star}$ \\
& 0.35 & 0.77 & & & & 0.26
\end{tabular}

$E=$ environmental variation; $D=$ component of variation due to additive gene effects; $H=$ component of variation due to dominant gene effects and $\sqrt{H / D}$ is the dominant ratio. Broad sense heritability $\left(h_{s l}^{2}\right)$ and narrow sense heritability $\left(h_{s s}^{2}\right)$ are computed for the $F_{2}$ generation. Standard deviations of variances and $h_{s s}^{2}$ are indicated in italics. * Significant at $P=0.05$; ${ }^{\star *}$ significant at $P=0.01$; ns: non-significant. 
Table III. Estimations of minimum number of effective factors for resistance to $P$ cubensis in 15 (resistant $\mathrm{x}$ susceptible) crosses according to the 4 formulae in equations [9]-[12].

$\begin{array}{llll}\mathrm{n}_{1} & \mathrm{n}_{2} & \mathrm{n}_{3}\end{array}$

MR-1

$\begin{array}{lllll}\text { x Charentais T } & 4.9 & 5.1 & 7.6 & 5.0 \\ \text { X Védrantais } & 5.4 & 3.3 & 3.4 & 5.4 \\ \text { x Ouzbèque } & 3.0 & 2.7 & 2.7 & 3.0\end{array}$

PI 124112

$x$ Charentais T

$x$ Ouzbèque

4.8

3.6

3.3

\section{7 \\ 2.2 \\ 3.0}

5.6
2.5
4.5

3.9

3.2

PI 164323

$x$ Charentais $\mathrm{T}$
$\times$ Védrantais
$x$ Ouzbèque

PI 414723
2.5

2.5

16

1.4
2.2
9

2.1

3.3

13 $n_{4}$

.

0


others might be at least partially recessive. The fact that $D$ and $H$, when significant, were approximately of the same value (dominance ratio $=1$ ) suggested that additive and dominance effects would be of the same amplitude.

However, in the case of 'MR-1 x Ouzbèque', we found a significant $[h]$ effect associated with a non-significant value of $H$ (implying that all $h_{i}$ effects were null). Thus $H$ estimation was not valid perhaps because of the presence of a significant environmental effect or because of the cumulation of imprecise estimations of variances of parental, $F_{2}$ and back-cross generations.

The methods employed to estimate the minimum number of effective factors were dependent upon the assumptions that there was no epistatic variation and that all genes had equal effects. Because of the presence of epistasis in 3 crosses and ambidirectional dominance in 5 crosses, the assumptions were obviously rarely met. So the formulae underestimate the number of segregating factors (Mather and Jinks, 1971) and all we could infer from the data was a minimum number of effective factors present in each genitor. These minimum numbers of factors were about 5 in 'MR-1', 4 in 'PI 124112', 3 in 'PI 164323', 2 in 'PI 414723' and 1 in 'Edisto 47'. Geiger and Heun (1989) reviewed on genetics of quantitative resistance in cereals and noted that the number of segregating factors commonly found ranged from 2 to 10 . Although these were underestimations, the number of segregating factors for resistance characters might be smaller than for typically polygenic characters such as height, yield and growth.

It is important to emphasize the effect that the susceptible parent had at all levels of the analysis. Generation means analysis clearly showed that the genetic models of the 3 crosses involving a single genitor were different depending on the recurrent parent. Genetic variance components exhibited a large variability among the 3 crosses involving 1 genitor. It implied that no common genetic behaviour could be traced for a single genitor through these data. As a comparison, $\mathrm{Kim}$ and Brewbaker (1977) studied the inheritance of general resistance in maize to Puccinia sorghi with the crosses of 5 resistant genitors to 5 susceptible varieties. They concluded that nonadditive or dominance genetic variances for the 25 sets of crosses varied substantially and somewhat inconsistently. Moreover, the susceptible parent effect is of considerable importance for the breeders' work, eg, the back-cross technique no longer held in such a situation because of the various interactions between alleles that could be encountered (resistance would be dominant within a cross involving a susceptible variety and recessive within a cross involving another).

In conclusion, resistance to downy mildew in the melon crosses studied was controlled primarily by additive gene effects. Dominance effects were ambidirectional and consequently had a low impact on phenotype; epistatic effects were of minor importance but could be either favourable or unfavourable. The introduction of these genes controlling resistance into horticulturally superior varieties would be facilitated through recurrent breeding methods. To select for $P$ cubensis resistance issued from a single genitor, however, large populations should be screened because of the moderate values of heritabilities. This fact, together with the importance of the susceptible parent involved, should discourage the use of the back-cross method commonly employed by muskmelon breeders. Likewise, single plant selections would be, in the particular case of 'Edisto 47', an ineffective practice because of low heritability. An appropriate breeding strategy would thus be based upon family selection.

However, some of the sources of resistance described here (particularly 'PI 414723' and 'Edisto 47') do not provide sufficient protection in environments where agressiveness is expressed at a high level. It may, however, provide some protection at moderate downy mildew epidemic levels. Combining these resistance sources together or with other sources such as 'MR-1', 'PI 124112 ' or 'PI 164323' may provide better and more widely adapted protection. We propose the establishment of connections between the recurrent breeding programs concerning each genitor. The objective would be to obtain $F_{1}$ hybrids with one parent coming from the improved population related to 'PI 124112' and the second parent coming from the improved population related to 'MR-1'. Thus, the breeder can control the kinship between the best lines and increase the variability for the resistance genes introduced in a cultivar. This could be a practical way to prevent rapid shifts in the pathogen population and so enhance durability of the resistance.

Finally, the genetic situation described, in which the character is controlled primarily by additive gene effects and relatively low heritabilities, is quite favourable for the introduction of molecular markers in selection scheme. Molecular markers (eg, the RFLP type) are not influenced by environmental conditions and could be introduced in the calculation of selection 
indexes as associated characters (Gallais, 1993). Indeed, information brought by molecular markers would the enhance precision of the estimations of genetic values and thus allow a more judicious choice of selected individuals.

\section{ACKNOWLEDGMENT}

We thanks M Ricard and C Ferrière for technical assistance.

\section{REFERENCES}

Blancard D, Pitrat M, Jourdain F (1989) Étude de la sporulation de $P$ cubensis sur cotylédons : application à la recherche de variétés de melon résistantes. Phytopathol Medit 3, 169-175

Bernardo R, Bourrier M, Olivier JL (1992) Generation means analysis of resistance to head smut in maize. agronomie 12, 303-306

Cavalli (1952) An analysis of linkage in quantitative inheritance. In: Quantitative Inheritance (ECR Reeve, $\mathrm{CH}$ Waddington, eds). HMSO, London, pp 135-144

Cohen $Y$ (1981) Downy Mildew of Cucurbits in the Downy Mildews. (DM Spencer, ed) Academic press, London, Chapter 16, 341-354

Cohen Y, Cohen S, Eyal H (1985) Inheritance of resistance to downy mildew in Cucumis melo Pl 124111. Cucurbit Genet Coop 8, 36-38

Épinat C (1992) Analyse génétique d'un plan de croisement diallèle pour les caractères de résistance du melon (Cucumis melo) au mildiou (Pseudoperonospora cubensis) et aux oïdiums (Sphaerotheca fuliginea et Erysiphe cichoracearum). Thèse de doctorat INA-PG $169 p$

Épinat C, Pitrat M (1994) Inheritance of resistance to downy mildew (Pseudoperonospora cubensis) in muskmelon (Cucumis melo). I. Analysis of an $8 \times 8$ diallel table. agronomie 14,

Gallais A (1993) La sélection assistée par marqueurs. Le sélectionneur français 43, 43-62

Geiger HH, Heun M (1989) Genetics of quantitative resistance to fungal diseases. Annu Rev Phytopathol 27, 317-341

Hautea RA, Coffman WR, Sorrels ME, Bergstrom GC (1987) Inheritance of partial resistance to powdery mildew in spring wheat. Theor Appl Genet 73, 609615

Kenigsbuch D, Cohen $Y$ (1989) Inheritance of resistance to downy mildew in a gynoecious muskmelon. Plant Dis 73, 994-96

Kenigsbuch D, Cohen $Y$ (1992) Inheritance of resistance to downy mildew in Cucumis melo PI 124112 and commonality of resistance genes with $\mathrm{Pl}$ 124111F. Plant Dis 76, 615-617

Ketata H, Edwards LH, Smith EL (1976) Inheritance of eight agronomic characters in a winter wheat cross. Crop Sci 16, 19-22

Kim SK, Brewbaker JL (1977) Inheritance of general resistance in maize to Puccinia sorghi Schw. Crop Sci 17, 456-461

Kozik E, Foolad MR, Jones RA (1991) Genetic analysis of resistance to Phytophthora root rot in tomato (Lycopersicon esculentum Mill). Plant Breeding 106, 27-32

Mather K, Jinks JL (1971) Biometrical Genetics. Chapman and Hall, 2nd Edition, London $382 \mathrm{pp}$

Scheffe H (1959) The Analysis of Variance. J Wiley and Sons, New York

Thomas CE, Cohen Y, McCreight JD, Jourdain EL (1988) Inheritance of resistance to downy mildew in Cucumis melo. Plant Dis 72, 33-35

Warner JN (1952) A method for estimating heritability. Agron J 44, 427-430

Wright $S$ (1968) The genetics of quantitative variability. In: Genetics and Biometric Foundations, Vol 1, Univ of Chicago Press, Chicago, Chapter 15, 373-420 